\title{
Penerapan Metode ROC dan Weighted Aggregated Sum Product Assesment (WASPAS) dalam Penerimaan Asisten Perkebunan
}

\author{
Rakhmi Khalida ${ }^{1}$, Budianto Bangun ${ }^{2, *}$, Mesran ${ }^{3}$, Nona Oktari ${ }^{3}$ \\ ${ }^{1}$ Prodi Teknik Informatika, Universitas Bhayangkara Jakarta Raya, Jakarta, Indonesia \\ ${ }^{2}$ Prodi Teknik Informatika, Universitas Labuhanbatu, Rantauprapat, Indonesia \\ ${ }^{3}$ Program Studi Teknik Informatika, Universitas Budi Darma, Medan, Indonesia \\ Email: ${ }^{1}$ rakhmi.khalida@dsn.ubharajaya.ac.id, ${ }^{2, *}$ budiantobangun44@gmail.com, ${ }^{3}$ mesran.skom.mkom@gmail.com, \\ ${ }^{4}$ nonaoktari460@gmail.com \\ Email Penulis Korespondensi: budiantobangun44@gmail.com
}

\begin{abstract}
Abstrak-Asisten perkebunan merupakan orang yang bertanggung jawab pada pengelolaan suatu kebun, dalam pemilihan asisten perkebunan masih terdapat kendala-kendala dalam penyeleksian, hal ini dikarenakan banyak pelamar yang masuk dan penilaian yang masih bersifat subyektif. Untuk mengatasi masalah tersebut, pada penelitian ini, penulis menggunakan metode Weighted Aggregated Sum Product Assessment (WASPAS) untuk menentukan penerimaan Asisten Perkebunan. Metode WASPAS dianggap sesuai dengan seleksi penerimaan asisten perkebunan, karena metode WASPAS akan melakukan proses perangkingan berdasarkan atribut dengan bobot yang berbeda-beda sehingga hasilnya menjadi lebih optimal. Untuk hasil yang lebih maksimal, penulis menggunakan pembobotan dengan menerapkan metode Rank Order Centroid (ROC). Hasil penelitian memberikan rekomendasi terhadap alternatif ke 8 memiliki nilai tertinggi dengan nilai 0.970 menjadi Asisten Perkebunan.
\end{abstract}

Kata Kunci: Asisten Perkebunan; SPK; WASPAS; ROC

Abstract-A plantation assistant is a person who is responsible for managing a plantation, in the selection of plantation assistants there are still obstacles in the selection, this is because many applicants enter and the assessment is still subjective. To overcome this problem, in this study, the author uses the Weighted Aggregated Sum Product Assessment (WSPAS) method to determine the acceptance of Plantation Assistants. The WASPAS method is considered in accordance with the selection of plantation assistants, because the WASPAS method will perform a ranking process based on attributes with different weights so that the results become more optimal. For maximum results, the author uses weighting by applying the Rank Order Centroid (ROC) method. The results of the study provide recommendations for the 8th alternative which has the highest value with a value of 0.970 to become a Plantation Assistant.

Keywords: Plantation Assistant; SPK; WASPAS; ROC

\section{PENDAHULUAN}

Asisten Perkebunan adalah orang yang diberikan tanggung jawab untuk memimpin afdeling (bagian/unit kebun) yang berperan sebagai pembantu/membantu, bisa membantu manajer dan karyawan dalam melaksakan segala jenis pekerjaan dilapangan. Agar dapat melaksanakan pekerjaannya dengan baik, seorang asisten dituntut untuk memiliki skill dan knowladge, mempunyai kemampuan menganalisa dan memecahkan masalah, mampu berorganisasi, memiliki motivasi, kemampuan komunikasi serta percaya diri yang kuat[1].

Asisten atau bisa juga disebut sebagai Kepala Afdeling sangat berperan penting dalam mengelola perkebunan. Manajemen dalam sebuah afdeling dapat berjalan bagus jika ada kepala afdeling (Asisten). Selain bertanggung jawab atas kegiatan agronomi, seorang asisten perkebunan juga bertanggung jawab atas terciptanya kondisi tempat kerja yang aman atas kemungkinan terjadinya kecelakaan dilingkungan kerja. Tidak kalah pentingnya adalah menciptakan dan membina hubungan yang harmonis dengan masyarakat setempat, khususnya pada perusahaan perkebunan. Mengingat peran seorang asisten perkebunan sangat dibutuhkan dalam mengelola kebun, untuk itu seorang manajer perkebunan dituntut untuk bijak pada saat merekrut calon asisten perkebunan yang akan di terima di perusahaan perkebunan. Pada penyeleksian penerimaan asisten perkebunan, terdapat beberapa kriteria yang harus dipenuhi, diantaranya yaitu pendidikan, pengalaman kerja, umur, wawasan, kedisiplinan serta kemampuan berkomunikasi. Namun tidak semua pelamar diterima, karena tidak memenuhi kriteria yang telah ditetapkan. Didalam melakukan proses penerimaan asisten perkebunan tersebut, memiliki beberapa kendala, diantaranya lamanya penyeleksian penerimaan asisten perkebunan dikarenakan banyaknya pelamar yang memasukkan lamarannya, maka dari itu diperlukan Sistem Pendukung Keputusan (SPK) untuk mengatasi masalah tersebut.

Sistem Pendukung Keputusan (SPK) merupakan sistem teknologi berbasis solusi yang menyediakan berbagai informasi untuk membantu dalam pengambilan keputusan baik pada situasi yang semi terstruktur dan situasi yang tidak terstruktur, dimana tidak seorangpun tahu secarapasti bagaimana keputusan seharusnya dibuat[2]-[4]. Dalam menghasilkan suatu keputusan Sistem Pendukung Keputusan (SPK) menggunakan metodemetode diantaranya WASPAS (Weighted Aggregated Sum Product Assesment), WP (Weighted Product), SAW (Simple Additive Weighting), TOPSIS, Promethee, ELECTRE, MOORA dan lain-lain[5]-[9]. Dalam penelitian ini penulis menggunakan metode WASPAS (Weighted Aggregated Sum Product Assessment) untuk menentukan pelamar yang berhak diterima sebagai Asisten Perkebunan [10]. Sistem Pendukung Keputusan merupakan solusi yang tepat dalam proses pemgambilan keputusan penerimaan asisten perkebunan. Adapun penelitian sebelumnya 
dilakukan oleh Royanti Manurung dkk (2018) bahwa dalam Penentuan Penerimaan Beasiswa Bidik Misi dengan menggunakan metode WASPAS dianggap mampu untuk menentukan secara akurat alternatif disemua masalah seleksi yang dipertimbangkan. Metode ini memiliki tujuan untuk mengevaluasi dan memberi peringkat alternatif yang ada sehingga lebih mudah menetukan siswa yang berhak mendapatkan pendidikan Bidik Misi[11]. Penelitian sebelumnya dilakukan oleh Muhammad Ickhsan pada tahun 2018 bahwa menentukan Penerimaan Siswa Miskin dalam metode WASPAS alternatif tertinggi merupakan alternatif terbaik[12].

Berdasarkan uraian penelitian sebelumnya, maka penulis mengambil penelitian untuk membuat Sistem Pendukung Keputusan Penerimaan Asisten Perkebunan Menggunakan Metode WASPAS (Weighted Aggregated Sum Product Assessment) di kombinasikan dengan metode Rank Order Centroid (ROC). Dalam penelitian juga penulis melakukan perangkingan terhadap kriteria-kriteria yang ditentukan untuk menentukan pelamar yang berhak diterima sebagai Asisten Perkebunan. Penerapan metode WASPAS dianggap mampu melakukan penilaian berdasarkan kriteria-kriteria dan diharapkan menghasilkan hasil yang tepat dan akurat serta mampu meminimalisir pekerjaan dalam penyeleksian Penerimaan Asisten Perkebunan.

\section{METODOLOGI PENELITIAN}

\subsection{Tahapan Penelitian}

Tahapan penelitian yang digunakan dalam proses penyelesaian penelitian ini padadasarnya merupakan urutan langkah-langkah yang harus dilakukan sehingga dihasilkan suatu sasaran akhir dari penelitian ini. Adapun tahapan penelitian yang digunakan sebagai berikut:

a. Studi Lapangan dan Pengumpulan data

Studi lapangan dan pengumpulan data merupakan tahapan penting dalam proses penelitian, karena hanya dengan mendapatkan data yang tepat proses penelitian akan berlangsung hingga penulis mendapatkan jawaban dari masalah yang telah dijelaskan di atas.

b. Studi Literatur dan Kajian Pustaka

Kajian pustaka merupakan tahapan penelitian yang dilakukan dengan cara melakukakan kajian mengenai teori-teori yang terkait berupa buku, artikel dan jurnal.

c. Tahapan Analisa

Proses analisa penelitian dilakukan apabila semua data yang dibutuhkan sudah lengkap. Tahap awal dalam analisa penelitian ini yaitu dimulai dengan menganalisa permasalahan yang terjadi dalam penerimaan Asisten. Dimulai dari menganalisa sistem lama yang masih secara manual perhitungannya. Setelah itu dilanjutkan dengan menganalisa sistem baru yang proses perhitungannya menggunakan metode WASPAS.

d. Tahapan Pengujian Metode

Tahapan pengujian metode merupakan tahapan penentuan untuk mengetahui apakah penerapan sistem menggunakan metode WASPAS sudah sesuai dengan tujuan yang akan dicapai. Sehingga dapat diketahui apakah metode WASPAS dapatmenjadi alternatif hasil perhitungan dalam penerimaan Asisten Perkebunan.

e. Tahapan Kesimpulan

Tahapan ini adalah tahapan akhir yang berisi kesimpulan hasil evaluasi seluruh tahapan kegiatan yang sudah dilakukan dalam penelitian penerimaan Asisten dan tahap untuk memberikan masukan dalam pengembangan sistem yang akan datang.

\subsection{Asisten Perkebunan}

Asisten Perkebunan adalah orang yang diberikan tanggung jawab untuk memimpinafdeling (bagian/unit kebun) yang berperan sebagai pembantu/membantu, bisa membantu manajer dan karyawan dalam melaksakan segala jenis pekerjaan dilapangan. Agar dapat melaksanakan pekerjaannya dengan baik, seorang asisten dituntut untuk memiliki skill dan knowladge, mempunyai kemampuan menganalisa dan memecahkan masalah, mampu berorganisasi, memiliki motivasi, kemampuan komunikasi serta percaya diri yang kuat[1].

\subsection{Sistem Pendukung Keputusan}

Sistem Pendukung Keputusan (SPK) merupakan sistem yang mampu memberikan kemampuan dalam memecahkan masalah yang sifatnya semi terstruktur maupun tidak terstruktur. Sistem ini digunakan untuk membantu untuk membantu dalam pengambilan keputusan, dimana tak seorang pun tahu secara pasti bagaimana keputusan seharusnya dibuat. Salah satu yang menjadi tujuan dari SPK ini adalah membantu dalam menyelesaikan masalah yang ada, serta mendukung manajer dalam mengambil keputusan suatu masalah[13][16].

\subsection{Metode Weighted Aggregated Sum Product Assessment (WASPAS)}

Metode Weighted Aggregated Sum Product Assessment (WASPAS) merupakan metode gabungan yang terdiri dari metode WP dan metode SAW, metode WASPAS ini diharapkan dapat memberikan hasil yang baik dalam 
membantu penentuan keputusan [5]-[7], [10], [17]-[21]. Adapun langkah-langkah dalam penyelesaian masalh menggunakan metode Weighted Aggregated Sum Product Assessment (WASPAS), sebagai berikut:

1. Membuat Matriks Keputusan

$$
x_{i j}=\left[\begin{array}{ccc}
x 11 & x 12 \ldots & x 1_{n} \\
x 21 & x 22 \ldots . & x 2_{n} \\
\cdots & \ldots . \cdots & \cdots \\
x_{m} 1 & x_{m} 2 \ldots & x_{m} n
\end{array}\right]
$$

Dimana $\mathrm{m}$ adalah jumlah alternatif kandidat, $\mathrm{n}$ adalah jumlah kriteria evaluasi dan $x_{i j}$ adalah kinerja alternatif sehubungan dengan kriteria $\mathrm{j}$.

2. Menormalisasikan matriks $x_{i j}$ sehingga menghasilkan matriks $x_{i j}^{*}$

a. Untuk kriteria keuntungan (benefit)

$$
x_{i j}^{*}=\frac{x_{i j}}{\max _{i} X_{i j}}
$$

b. Untuk kriteria biaya (cost).

$$
x_{i j}^{*}=\frac{\min _{i} x_{i j}}{x_{i j}}
$$

3. Menghitung nilai normalisasi matriks dan bobot WASPAS dalam pengambilan keputusan.

$$
\mathrm{Qi}=0,5 \sum_{j=1}^{n} x_{i j}^{*} w_{j}+0,5 \prod_{j=1}^{n} x_{i j}^{*}{ }^{W j}
$$

Pada metode WASPAS Qi yang tertinggi maka merupakan alternatif yang terbaik.

\section{HASIL DAN PEMBAHASAN}

Salah satu yang dihadapi dalam penyeleksian penerimaan asisten perkebunan yaitu dikarenakan banyaknya yang mendaftar, maka dari itu untuk penentuan penerimaan asisten perkebunan pihak perusahaan melakukan pendataan dengan menentukan kriteria-kriteria dan bobot yang harus dipenuhi untuk melakukan perhitungannya, sehingga dapat diperoleh hasil alternatif terbaik.

\subsection{Penentuan Kriteria, Bobot dan Alternatif}

Berdasarkan hal ini, penulis membuat Sistem Pendukung Keputusan dalam Penerimaan Asisten Perkebunan menggunakan metode Weighted Aggregated Sum Product Assesment (WASPAS). Beberapa kriteria yang digunakan dalam penerimaan asisten perkebunan yaitu Pendidikan $\left(\mathrm{C}_{1}\right)$, Umur $\left(\mathrm{C}_{2}\right)$, Pengalaman $\operatorname{Kerja}\left(\mathrm{C}_{3}\right)$, Kedisiplinan $\left(\mathrm{C}_{4}\right)$, Wawasan $\left(\mathrm{C}_{5}\right)$, Kemampuan Berkomunikasi $\left(\mathrm{C}_{6}\right)$. Untuk penentuan bobot penulis menerapkan metode Rank Order Centroid (ROC) yang terlihat pada persamaan 5 [22], [23] berikut.

$$
W_{m}=\frac{1}{m} \sum_{1=1}^{m}\left(\frac{1}{i}\right)
$$

Dari rumus Rank Order Centroid (ROC) maka dari dilihat bobot yang dihasilkan sebagai berikut.

$$
\begin{aligned}
& W_{1}=\frac{1+\frac{1}{2}+\frac{1}{3}+\frac{1}{4}+\frac{1}{5}+\frac{1}{6}}{6}=0,41 \\
& W_{2}=\frac{0+\frac{1}{2}+\frac{1}{3}+\frac{1}{4}+\frac{1}{5}+\frac{1}{6}}{6}=0,24 \\
& W_{3}=\frac{0+0+\frac{1}{3}+\frac{1}{4}+\frac{1}{5}+\frac{1}{6}}{6}=0,16 \\
& W_{4}=\frac{0+0+0+\frac{1}{4}+\frac{1}{5}+\frac{1}{6}}{6}=0,10 \\
& W_{5}=\frac{0+0+0+0+\frac{1}{5}+\frac{1}{6}}{6}=0,06 \\
& W_{6}=\frac{0+0+0+0+0+\frac{1}{6}}{6}=0,03
\end{aligned}
$$

Hasil bobot jika di jumlahkan bernilai 1, sehingga nilai bobot pada tiap tiap kriteria dapat terlihat pada tabel 1 berikut ini. 
JURNAL MEDIA INFORMATIKA BUDIDARMA

Volume 5, Nomor 3, Juli 2021, Page 937-944

ISSN 2614-5278 (media cetak), ISSN 2548-8368 (media online)

Available Online at https://ejurnal.stmik-budidarma.ac.id/index.php/mib

DOI 10.30865/mib.v5i3.3092

Tabel 1. Bobot tiap kriteria

\begin{tabular}{lcc}
\hline Kriteria & Bobot & Jenis \\
\hline Pendidikan $\left(\mathrm{C}_{1}\right)$ & 0.41 & Benefit \\
Umur $\left(\mathrm{C}_{2}\right)$ & 0.24 & Cost \\
Pengalaman Kerja $\left(\mathrm{C}_{3}\right)$ & 0.16 & Benefit \\
Kedisiplinan $\left(\mathrm{C}_{4}\right)$ & 0.10 & Benefit \\
Wawasan $\left(\mathrm{C}_{5}\right)$, & 0.06 & Benefit \\
Kemampuan Berkomunikasi $\left(\mathrm{C}_{6}\right)$ & 0.03 & Benefit \\
\hline
\end{tabular}

Berikut pada tabel 2 merupakan nilai alternatif pada tiap-tiap kriteria.

Tabel 2. Nilai Alternatif di Setiap Kriteria

\begin{tabular}{lllllll}
\hline \multicolumn{1}{c}{ Alternatif } & \multicolumn{5}{c}{ Kriteria/Tingkat } \\
& $\mathrm{C}_{1}$ & $\mathrm{C}_{2}$ & \multicolumn{1}{c}{$\mathrm{C}_{3}$} & \multicolumn{1}{c}{ C4 } & \multicolumn{1}{c}{ C6 } \\
\hline Dani $\left(\mathrm{A}_{1}\right)$ & $\mathrm{S} 1$ & 27 & 1 Tahun & Sangat Baik & Baik & Cukup Baik \\
Surya $\left(\mathrm{A}_{2}\right)$ & $\mathrm{S} 1$ & 28 & 2 Tahun & Baik & Sangat Baik & Baik \\
Wildan $\left(\mathrm{A}_{3}\right)$ & $\mathrm{D} 3$ & 26 & 1 Tahun & Baik & Cukup Baik & Baik \\
Roni $\left(\mathrm{A}_{4}\right)$ & $\mathrm{S} 2$ & 28 & 3 Tahun & Cukup Baik & Baik & Cukup Baik \\
Choiri $\left(\mathrm{A}_{5}\right)$ & $\mathrm{S} 2$ & 27 & 2 Tahun & Sangat Baik & Baik & Baik \\
Syahril $\left(\mathrm{A}_{6}\right)$ & $\mathrm{S} 1$ & 26 & 2 Tahun & Baik & Sangat Baik & Baik \\
Richardo $\left(\mathrm{A}_{7}\right)$ & $\mathrm{D} 3$ & 27 & 1Tahun & Baik & Sangat Baik & Cukup Baik \\
Jimmy $\left(\mathrm{A}_{8}\right)$ & $\mathrm{S} 2$ & 28 & 3 Tahun & Sangat Baik & Baik & Baik \\
Suryadi $\left(\mathrm{A}_{9}\right)$ & $\mathrm{S} 1$ & 27 & 1 Tahun & Baik & Baik & Baik \\
Amrizal $\left(\mathrm{A}_{10}\right)$ & $\mathrm{D} 3$ & 28 & 2 Tahun & Sangat Baik & Baik & Cukup Baik \\
\hline
\end{tabular}

Untuk $\mathrm{C}_{1}, \mathrm{C}_{3}, \mathrm{C}_{4}, \mathrm{C}_{5}$ dan $\mathrm{C}_{6}$ merupakan kriteria benefit, sedangkan $\mathrm{C}_{2}$ merupakan kriteria Cost. Karena kriteria $\mathrm{C}_{1}, \mathrm{C}_{4}, \mathrm{C}_{5}$ dan $\mathrm{C}_{6}$ merupakan kriteria linguistik, maka harus dibobotkan terlebih dahulu. Penentuan bobot dari setiap kriteria $\left(w_{j}\right)$ bentuk dalam tabel berikut ini:

Tabel 3. Kriteria Pendidikan

\begin{tabular}{ccc}
\hline No & Pendidikan $\left(\mathrm{C}_{1}\right)$ & Nilai Kriteria \\
\hline 1 & SMA & 1 \\
2 & D3 & 2 \\
3 & S1 & 3 \\
4 & S2 & 4 \\
\hline
\end{tabular}

Tabel 4. Pembobotan untuk $\mathrm{C}_{4}, \mathrm{C}_{5}$ dan $\mathrm{C}_{6}$

\begin{tabular}{ccc}
\hline No & Keterangan & Nilai Kriteria \\
\hline 1 & Sangat Baik & 5 \\
2 & Baik & 4 \\
3 & Cukup Baik & 3 \\
4 & Kurang Baik & 2 \\
\hline
\end{tabular}

Dari tabel 1, merupakan alternatif yang masih memiliki nilai linguistik, maka digunakan tabel 2 dan tabel 3 untuk pembobotan dengan skala sederhana, sehingga di peroleh tabel 4 yang merupakan rating kecocokan dari hasil pembobotan terhadap nilai alternatif sebelumnya.

Tabel 5. Rating Kecocokan

\begin{tabular}{lcccccc}
\hline Alternatif & $\mathrm{C}_{1}$ & $\mathrm{C}_{2}$ & $\mathrm{C}_{3}$ & $\mathrm{C}_{4}$ & $\mathrm{C}_{5}$ & $\mathrm{C}_{6}$ \\
\hline Dani $\left(\mathrm{A}_{1}\right)$ & 3 & 27 & 1 & 5 & 4 & 3 \\
Surya $\left(\mathrm{A}_{2}\right)$ & 3 & 28 & 2 & 4 & 5 & 4 \\
Wildan $\left(\mathrm{A}_{3}\right)$ & 2 & 26 & 1 & 4 & 3 & 4 \\
Roni $\left(\mathrm{A}_{4}\right)$ & 4 & 28 & 3 & 3 & 4 & 3 \\
Choiri $\left(\mathrm{A}_{5}\right)$ & 4 & 27 & 2 & 5 & 4 & 4 \\
Syahril $\left(\mathrm{A}_{6}\right)$ & 3 & 26 & 2 & 4 & 5 & 4 \\
Richardo $\left(\mathrm{A}_{7}\right)$ & 2 & 27 & 1 & 4 & 5 & 3 \\
Jimmy $\left(\mathrm{A}_{8}\right)$ & 4 & 28 & 3 & 5 & 4 & 4 \\
Suryadi $\left(\mathrm{A}_{9}\right)$ & 3 & 27 & 1 & 4 & 4 & 4 \\
Amrizal $\left(\mathrm{A}_{10}\right)$ & 2 & 28 & 2 & 5 & 4 & 3 \\
\hline
\end{tabular}


ISSN 2614-5278 (media cetak), ISSN 2548-8368 (media online)

Available Online at https://ejurnal.stmik-budidarma.ac.id/index.php/mib DOI 10.30865/mib.v5i3.3092

\subsection{Penerapan Metode WASPAS}

Tahapan penerapan metode WASPAS dalam penyeleksian penerimaan asisten perkebunan sehingga menghasilkan alternatif terbaik yang dapat direkomendasikan, sebagai berikut:

1. Mempersiapkan Matrik Keputusan

Matrik keputusan berikut merupakan data yang diperoleh dari tabel 5, yang merupakan rating kecocokan setelah di bobotkan.

$R_{i j}=\left[\begin{array}{llllll}3 & 27 & 1 & 5 & 4 & 3 \\ 3 & 28 & 2 & 4 & 5 & 4 \\ 2 & 26 & 1 & 4 & 3 & 4 \\ 4 & 28 & 3 & 3 & 4 & 3 \\ 4 & 27 & 2 & 5 & 4 & 4 \\ 3 & 26 & 2 & 4 & 5 & 4 \\ 2 & 27 & 1 & 4 & 5 & 3 \\ 4 & 28 & 3 & 5 & 4 & 4 \\ 3 & 27 & 1 & 4 & 4 & 4 \\ 2 & 28 & 2 & 5 & 4 & 3\end{array}\right]$

Pada matrik keputusan di atas, maka di ambil nilai maksimum/minimun sesuai dengan jenis dari tiap tiap kriteria.

Maximum/Minimum $\{4 ; 26 ; 3 ; 5 ; 5 ; 4\}$

2. Menghitung Matriks Ternormalisasi

Untuk Kriteria $\mathrm{C}_{1}$ (Pendidikan: Benefit) dengan menggunakan persamaan 2.

$\begin{array}{llc}\mathrm{x}^{*}{ }_{1,1} & =3 / 4 & =0,750 \\ \mathrm{x}^{*}{ }_{2,1} & =3 / 4 & =0,750 \\ \mathrm{x}^{*}{ }_{3,1} & =2 / 4 & =0,500 \\ \mathrm{x}^{*}{ }_{4,1} & =4 / 4 & =1,000 \\ \mathrm{x}^{*}{ }_{5,1} & =4 / 4 & =1,000 \\ \mathrm{x}^{*}{ }_{6,1} & =3 / 4 & =0,750 \\ \mathrm{x}^{*}{ }^{7,1} & =2 / 4 & =0,500 \\ \mathrm{x}^{*}{ }^{8,1} & =4 / 4 & =1,000 \\ \mathrm{x}^{*}{ }_{9,1} & =3 / 4 & =0,750 \\ \mathrm{x}^{*}{ }_{10,1} & =2 / 4 & =0,500\end{array}$

Untuk Kriteria $\mathrm{C}_{2}$ (Umur: Cost) dengan menggunakan persamaan 3.

$$
\begin{array}{ll}
\mathrm{x}^{*}{ }_{1,2} & =26 / 27=0,963 \\
\mathrm{x}^{*}{ }_{2,2} & =26 / 28=0,929 \\
\mathrm{x}^{*}{ }_{3,2} & =26 / 26=1,000 \\
\mathrm{x}^{*}{ }_{4,2} & =26 / 28=0,929 \\
\mathrm{x}^{*}{ }_{5,2} & =26 / 27=0,963 \\
\mathrm{x}^{*}{ }_{6,2} & =26 / 26=1,000 \\
\mathrm{x}^{*}{ }_{7,2} & =26 / 27=0,963 \\
\mathrm{x}^{*}{ }_{8,2} & =26 / 28=0,929 \\
\mathrm{x}^{*}{ }_{9,2} & =26 / 27=0,963 \\
\mathrm{x}^{*}{ }_{10,2} & =26 / 28=0,929
\end{array}
$$

Untuk Kriteria $\mathrm{C}_{3}$ (Pengalaman Kerja: Benefit) dengan menggunakan persamaan 2.

$\begin{array}{lll}\mathrm{x}^{*}{ }_{1,3} & =1 / 3 & =0,333333 \\ \mathrm{x}^{*}{ }_{2,3} & =2 / 3 & =0,666667 \\ \mathrm{x}^{*}{ }_{3,3} & =1 / 3 & =0,333333 \\ \mathrm{x}^{*}{ }_{4,3} & =3 / 3 & =1,000000 \\ \mathrm{x}^{*}{ }_{5,3} & =2 / 3 & =0,666667 \\ \mathrm{x}^{*}{ }_{6,3} & =2 / 3 & =0,666667 \\ \mathrm{x}^{*}{ }^{*}, 3 & =1 / 3 & =0,333333 \\ \mathrm{x}^{*}{ }_{8,3} & =3 / 3 & =1,000000 \\ \mathrm{x}^{*}{ }_{9,3} & =1 / 3 & =0,333333 \\ \mathrm{x}^{*}{ }_{10,3} & =2 / 3 & =0,666667\end{array}$

Untuk Kriteria $\mathrm{C}_{4}$ (Kedisiplinan: Benefit) dengan menggunakan persamaan 2.

$\mathrm{x}^{*}{ }_{1,4}=5 / 5=1,000$ 
JURNAL MEDIA INFORMATIKA BUDIDARMA

Volume 5, Nomor 3, Juli 2021, Page 937-944

ISSN 2614-5278 (media cetak), ISSN 2548-8368 (media online)

Available Online at https://ejurnal.stmik-budidarma.ac.id/index.php/mib DOI 10.30865/mib.v5i3.3092

$$
\begin{array}{lll}
\mathrm{x}^{*}{ }_{2,4} & =4 / 5 & =0,800 \\
\mathrm{x}^{*}{ }_{3,4} & =4 / 5 & =0,800 \\
\mathrm{x}^{*}{ }_{4,4} & =3 / 5 & =0,600 \\
\mathrm{x}^{*}{ }_{5,4} & =5 / 5 & =1,000 \\
\mathrm{x}^{*}{ }_{6,4} & =4 / 5 & =0,800 \\
\mathrm{x}^{*}{ }_{7,4} & =4 / 5 & =0,800 \\
\mathrm{x}^{*}{ }^{*}, 4 & =5 / 5 & =1,000 \\
\mathrm{x}^{*}{ }_{9,4} & =4 / 5 & =0,800 \\
\mathrm{x}^{*}{ }_{10,4} & =5 / 5 & =1,000
\end{array}
$$

Untuk Kriteria $\mathrm{C}_{5}$ (Wawasan: Benefit) dengan menggunakan persamaan 2.

$$
\begin{array}{lll}
\mathrm{x}^{*}{ }_{1,5} & =4 / 5 & =0,800 \\
\mathrm{x}^{*}{ }^{2,5} & =5 / 5 & =1,000 \\
\mathrm{x}^{*}{ }_{3,5} & =3 / 5 & =0,600 \\
\mathrm{x}^{*}{ }_{4,5} & =4 / 5 & =0,800 \\
\mathrm{x}^{*}{ }_{5,5} & =4 / 5 & =0,800 \\
\mathrm{x}^{*}{ }^{*}, 5 & =5 / 5 & =1,000 \\
\mathrm{x}^{*}{ }^{*}, 5 & =3 / 5 & =0,600 \\
\mathrm{x}^{*}{ }^{*}, 5 & =4 / 5 & =0,800 \\
\mathrm{x}^{*}{ }_{9,5} & =3 / 5 & =0,600 \\
\mathrm{x}^{*}{ }_{10,5} & =4 / 5 & =0,800
\end{array}
$$

Untuk Kriteria $\mathrm{C}_{6}$ (Kemampuan Berkomunikasi: Benefit) dengan menggunakan persamaan 2.

$$
\begin{array}{lll}
\mathrm{x}^{*}{ }_{1,6} & =3 / 4 & =0,750 \\
\mathrm{x}^{*}{ }_{2,6} & =4 / 4 & =1,000 \\
\mathrm{x}^{*}{ }_{3,6} & =4 / 4 & =1,000 \\
\mathrm{x}^{*}{ }_{4,6} & =3 / 4 & =0,750 \\
\mathrm{x}^{*}{ }_{5,6} & =3 / 4 & =0,750 \\
\mathrm{x}^{*}{ }^{*}, 6 & =4 / 4 & =1,000 \\
\mathrm{x}^{*}{ }^{*}, 6 & =4 / 4 & =1,000 \\
\mathrm{x}^{*}{ }^{*}, 6 & =3 / 4 & =0,750 \\
\mathrm{x}_{9,6}{ }_{9,6} & =4 / 4 & =1,000 \\
\mathrm{x}^{*}{ }^{*}, 6 & =3 / 4 & =0,750
\end{array}
$$

Hasil yang diperoleh untuk matrik ternormalisasi $\left(x_{i j}^{*}\right)$ yaitu:

$$
x_{i j}^{*}=\left|\begin{array}{cccccc}
0.750 & 0.963 & 0.333 & 1.000 & 0.800 & 0.750 \\
0.750 & 0.929 & 0.667 & 0.800 & 1.000 & 1.000 \\
0.500 & 1.000 & 0.333 & 0.800 & 0.600 & 1.000 \\
1.000 & 0.929 & 1.000 & 0.600 & 0.800 & 0.750 \\
1.000 & 0.963 & 0.667 & 1.000 & 0.800 & 1.000 \\
0.750 & 1.000 & 0.667 & 0.800 & 1.000 & 1.000 \\
0.500 & 0.963 & 0.333 & 0.800 & 1.000 & 0.750 \\
1.000 & 0.929 & 1.000 & 1.000 & 0.800 & 1.000 \\
0.750 & 0.963 & 0.333 & 0.800 & 0.800 & 1.000 \\
0.500 & 0.929 & 0.667 & 1.000 & 0.800 & 0.750
\end{array}\right|
$$

3. Menghitung total Kepentingan Relatif (Qi), dengan menggunakan persamaan 4.

$\mathbf{Q}_{\mathbf{1}}=0,5 \sum((0,750 * 0,41)+(0,963 * 0,24)+(0,333 * 0,16)+(1,000 * 0,1)+(0,800 * 0,06)+(0,750 * 0,03))+$ $0,5 \prod\left(\left(0,750^{0,41}\right) *\left(0,963^{0,24}\right) *\left(0,333^{0,16}\right) *\left(1,000^{0,1}\right) *\left(0,800^{0,06}\right) *\left(0,7500^{0,03}\right)\right)=0,381+0,361=$ 0,743

$\mathbf{Q}_{2}=0,5 \sum((0,750 * 0,41)+(0,929 * 0,24)+(0,667 * 0,16)+(0,800 * 0,1)+(1.000 * 0,06)+(1,000 * 0,03))+$ $0,5 \prod\left(\left(0,750^{0,41}\right) *\left(0,929^{0,24}\right) *\left(0,667^{0,16}\right) *\left(0,800^{0,1}\right) *\left(1,000^{0,06}\right) *\left(1,000^{0,03}\right)\right)=0,404+0,400=$ 0,804

Selanjutnya perhitungan pada $\mathrm{Q}_{3}$ hingga $\mathrm{Q}_{10}$ dilakukan juga pada alternatif ke 3 hingga ke alternatif ke 10. Hasil akhir nilai Qi dapat dilihat pada tabel 6 berikut ini.

Tabel 6. Hasil Perhitungan Akhir

\begin{tabular}{cccc}
\hline Alternatif & Nama & Qi & Peringkat \\
\hline $\mathrm{A}_{1}$ & Dani & 0.743 & 6 \\
\hline
\end{tabular}


ISSN 2614-5278 (media cetak), ISSN 2548-8368 (media online)

Available Online at https://ejurnal.stmik-budidarma.ac.id/index.php/mib DOI 10.30865/mib.v5i3.3092

\begin{tabular}{clcc}
\hline Alternatif & Nama & Qi & Peringkat \\
\hline $\mathrm{A}_{2}$ & Surya & 0.804 & 5 \\
$\mathrm{~A}_{3}$ & Wildan & 0.622 & 10 \\
$\mathrm{~A}_{4}$ & Roni & 0.918 & 3 \\
$\mathrm{~A}_{5}$ & Choiri & 0.921 & 2 \\
$\mathrm{~A}_{6}$ & Syahril & 0.819 & 4 \\
$\mathrm{~A}_{7}$ & Richardo & 0.629 & 9 \\
$\mathrm{~A}_{8}$ & Jimmy & 0.970 & 1 \\
$\mathrm{~A}_{9}$ & Suryadi & 0.731 & 7 \\
$\mathrm{~A}_{10}$ & Amrizal & 0.691 & 8 \\
\hline
\end{tabular}

Berdasarkan pada tabel 6 di atas, terlihat bahwa Jimmy memiliki prioritas yang paling tinggi untuk dapat diterima sebagai Asisten Perkebunan, karena memiliki rangking yang tertinggi bila dibandingkan dengan alternatif yang lainnya.

\section{KESIMPULAN}

Dari pembahasan yang telah diuraikan di atas, maka dapat ditarik kesimpulan dalam penerimaan Asisten Perkebunan dengan menggunakan metode WASPAS (Weighted Aggregated Sum Product Assessment) dapat membantu manajer perkebunan dalam pengambilan keputusan untuk memutuskan satu atau lebih dari beberapa alternatif yang harus diambil untuk dijadikan sebagai penerimaan asisten perkebunan berdasarkan kriteria yang telah ditetapkan sebagai bahan pertimbangan. Metode Rank Order Centroid (ROC) mampu memberikan hasil pembobotan yang lebih baik, karena kriteria di urutkan dari yang lebih penting terlebih dahulu. Dari hasil penelitian dapat di rekomendasikan alternatif $\mathrm{A}_{8}$ atas nama Jimmy dengan nilai 0,970 merupakan alternatif terbaik sebagai asisten perkebunan.

\section{REFERENCES}

[1] F. Pratiwi, Fince Tinus Waruwu, D. P. Utomo, and R. Syahputra, "Penerapan Metode Aras Dalam Pemilihan Asisten Perkebunan Terbaik Pada PTPN V," in Seminar Nasional Teknologi Komputer \& Sains (SAINTEKS), 2019, pp. 651662.

[2] E. Ningsih, D. Dedih, and S. Supriyadi, "Sistem Pendukung Keputusan Menentukan Peluang Usaha Makanan Yang Tepat Menggunakan Weighted Product (Wp) Berbasis Web,” Ilk. J. Ilm., vol. 9, no. 3, pp. 244-254, 2017.

[3] Efraim Turban and Jay E. Aronson, Decision Support System and Intelligent Systems. 2001.

[4] D. Nofriansyah, Multi Criteria Decision Making. Yogyakarta: Deepublish, 2017.

[5] N. K. Daulay, "Penerapan Metode Waspas Untuk Efektifitas Pengambilan Keputusan Pemutusan Hubungan Kerja," $J$. Sist. Komput. dan Inform., vol. 2, no. 2, pp. 196-201, 2021.

[6] N. K. Daulay, B. Intan, and M. Irvai, "Comparison of the WASPAS and MOORA Methods in Providing Single Tuition Scholarships," IJICS (International J. Informatics Comput. Sci., vol. 5, no. 1, pp. 84-94, 2021.

[7] A. T. Hidayat, N. K. Daulay, and Mesran, "Penerapan Metode Multi-Objective Optimization on The Basis of Ratio Analysis (MOORA) dalam Pemilihan Wiraniaga Terbaik," J. Comput. Syst. Informatics, vol. 1, no. 4, pp. 367-372, 2020.

[8] Mesran, E. P. Sumantri, Supriyanto, S. H. Sahir, and N. K. Daulay, "Implementation of Technique for Order Preference by Similarity to Ideal Solution ( TOPSIS ) in Recommendations for New Position in Companies," Int. J. Inf. Syst. Technol., vol. 4, no. 2, pp. 661-669, 2021.

[9] S. H. Sahir, R. Rosmawati, and K. Minan, "Simple Additive Weighting Method to Determining Employee Salary Increase Rate," Int. J. Sci. Res. Sci. Technol., vol. 3, no. 8, pp. 42-48, 2017.

[10] sufri yono Hutagalung, F. Pratiwi, and I. Wijaya, "Penerapan Metode Weighted Aggregated Sum Product Assesment (WASPAS) Dalam Keputusan Penerimaan Beasiswa,” Ris. Komput., 2018.

[11] R. Manurung, R. Sitanggang, and F. T. Waruwu, "Penerapan Metode Weighted Aggregated Sum Product Assessment Dalam Penentuan Penerima Beasiswa Bidik Misi," vol. 5, no. 1, pp. 79-84, 2018.

[12] N. W. Al-Hafiz, Mesran, and Suginam, "Sistem Pendukung Keputusan Penentukan Kredit Pemilikan Rumah Menerapkan Multi-Objective Optimization on the Basis of Ratio Analysis ( Moora )," KOMIK (Konferensi Nas. Teknol. Inf. dan Komputer), vol. I, no. 1, pp. 306-309, 2017.

[13] T. Limbong et al., Sistem Pendukung Keputusan: Metode \& Implementasi. Medan: Yayasan Kita Menulis, 2020.

[14] D. Nofriansyah and S. Defit, Multi Criteria Decision Making (MCDM) pada Sistem Pendukung Keputusan. 2018.

[15] D. Nofriansyah, Konsep Data Mining Vs Sistem Pendukung Keputusan. 2015.

[16] S. Kusumadewi, S. Hartati, A. Harjoko, and Retantyo Wardoyo, Fuzzy Multi-Attribute Decision Making (FUZZY MADM). 2006.

[17] S. Chakraborty, E. K. Zavadskas, and J. Antucheviciene, "Applications of WASPAS Method as a Multi-Criteria Decision-Making Tool,” Econ. Comput. Econ. Cybern. Stud. Res., vol. 49, no. 1, pp. 1-17, 2015.

[18] S. M. Harahap, I. J. T. Situmeang, S. Hummairoh, and Mesran, "Implementation of Weighted Aggregated Sum Product Assessment ( WASPAS ) in Determining the Best Graduates," IJICS (International J. Informatics Comput. Sci., vol. 5, no. 1, pp. 44-51, 2021.

[19] V. Amalia, D. Syamsuar, and L. Atika, "Komparasi Metode WP SAW dan WASPAS Dalam Penentuan Penerima 
ISSN 2614-5278 (media cetak), ISSN 2548-8368 (media online)

Available Online at https://ejurnal.stmik-budidarma.ac.id/index.php/mib DOI 10.30865/mib.v5i3.3092

Beasiswa Penelusuran Minat dan Kemampuan,” J. Inform., vol. 6, no. 1, pp. 114-121, 2019.

[20] R. Manurung, Fitriani, Retnowati Sitanggang, F. T. Waruwu, and Fadlina, "Penerapan Metode Weighted Aggregated Sum Product Assesment ( WASPAS ) Dalam Keputusan Penerimaan Beasiswa Bidik Misi,” JURIKOM (Jurnal Ris. Komputer), vol. 5, no. 1, pp. 148-151, 2018.

[21] N. Lestari, J. Karman, and B. Santoso, "Komparasi Metode Weighted Aggregated Sum Product Assessment (WASPAS) dan Multi-Objective Optimization on The Basis of Ratio (MOORA) Dalam Penerimaan Dosen," J. Inf. Syst. Res., vol. 2, no. 2, pp. 138-147, 2021.

[22] M. Mesran, J. Afriany, and S. H. Sahir, "Efektifitas Penilaian Kinerja Karyawan Dalam Peningkatan Motivasi Kerja Menerapkan Metode Rank Order Centroid (ROC) dan Additive Ratio Assessment (ARAS)," Pros. Semin. Nas. Ris. Inf. Sci., vol. 1, no. 0, pp. 813-821, Sep. 2019.

[23] M. Mesran, T. M. Diansyah, and F. Fadlina, "Implemententasi Metode Rank Order Cendroid (ROC) dan Operational Competitiveness Rating Analysis (OCRA) dalam Penilaian Kinerja Dosen Komputer Menerapkan (Studi Kasus: STMIK Budi Darma),” Pros. Semin. Nas. Ris. Inf. Sci., vol. 1, no. September, p. 822, 2019. 